\title{
Effect of Acupuncture Therapy on Pain Reduction in Dysmenorrhea Patients: A Meta-Analysis
}

\author{
Elisa Novitasari'1), RB Soemanto²), Hanung Prasetya3) \\ ${ }^{1)}$ Masters Program in Public Health, Universitas Sebelas Maret \\ 2)Departement of Social and Political Sciences, Universitas Sebelas Maret \\ 3)Study Program of Acupuncture, Health Polytechnics, Ministry of Health Surakarta
}

\section{ABSTRACT}

Background: Dysmenorrhea is a common complaint that usually occurs in adolescent girls and women of reproductive age. Dysmenorrhea is not a disease, but a symptom that occurs due to abnormalities in the pelvic cavity and greatly disrupts women's activities. Acupuncture therapy is a therapeutic method by inserting a needle at the acupoint to reduce pain in dysmenorrhea patients. This study aimed to estimate how great the effect of acupuncture therapy on pain reduction in dysmenorrhea patients based on the results of previous studies.

Subjects and Method: This study was a systematic study and a meta-analysis, with the following PICO: Population= dysmenorrhea patients aged 14-40 years, Intervention= acupuncture therapy, Comparison= no acupuncture therapy, and Outcome $=$ pain reduction in dysmenorrhea patients. The articles were obtained from several databases including PubMed, Google scholar, and Hindawi. These articles were collected for 1 month. The keywords were "acupuncture pain" OR "acupuncture primary dysmenorrhea" AND "acupuncture for dysmenorrhea" AND "randomized controlled trial". The included articles were full-text articles with a randomized controlled trial study design. The articles were collected using PRISMA flow diagram. These articles were analyzed using the Review Manager (RevMan) 5.3 application.

Results: 7 articles from South Korea, Taiwan, Spain, China, India, and Hong Kong were reviewed in this meta-analysis. This study showed that acupuncture therapy was -1.16 better in reducing pain in dysmenorrhea patients (Standardized Mean Difference $=-1.16 ; 95 \% \mathrm{CI}=-$ 1.92 to $-0.41 ; \mathrm{p}=0.003$ ).

Conclusion: Acupuncture therapy can affect pain reduction in dysmenorrhea patients.

Keywords: Acupuncture pain, Acupuncture dysmenorrhea, Primary dysmenorrhea

\section{Correspondence:}

Elisa Novitasari, Masters Program In Public Health, Universitas Sebelas Maret, Jl. Ir. Sutami 36A, Surakarta 57126, Central Java, Indonesia. Email: elisanovita58@gmail.com.

Cite this as:

Novitasari E, Soemanto RB, Prasetya H (2020). Effect of Acupuncture Therapy on Pain Reduction in Dysmenorrhea Patients: A Meta-Analysis. J Matern Child Health. 05(06): 705-714. https://doi.org/10.26911/thejmch.2020.05.06.10.

(c) (F) (-) Journal of Maternal and Child Health is licensed under a Creative Commons Attribution-Non Commercial-Share Alike 4.o International License.

\section{BACKGROUND}

Puberty occurs in adolescents aged 10-19 years. It is a period of maturation of the human reproductive organs. The maturity of the reproductive organs of adolescent girls is characterized by menstruation. This menstrual cycle occurs periodically every month with a normal span of 28 days while the men- strual period occurs between 3-7 days (Rahayu et al., 2017).

Dysmenorrhea is a common complaint that usually occurs in adolescent girls or women of reproductive age (Yu et al., 2014). Dysmenorrhea occurs due to contractions in the uterus or uterine muscles. If there is a strong contraction during menstruation, the 
oxygen supply to the uterus will decrease, thus causing pain (Pratiwi et al., 2016).

Dysmenorrhea is a reproductive health problem in women which had a prevalence of around 50-9-\% in the world (Joshi et al., 2015). According to the World Health Organization (WHO), the incidence of dysmenorrhea was quite high throughout the world. The incidence of dysmenorrhea in young women was 16.8-81\%. In European countries, dysmenorrhea in women was 45-97\%. In the United States, dysmenorrhea is the most common cause of the absence of adolescent girls at school. Based on a survey conducted on 113 women in the United States, the prevalence of dysmenorrhea was $29-44 \%$, mostly at the age of $18-45$ years (Sulisyorini et al., 2017).

Dysmenorrhea is characterized by lower abdominal pain followed by other symptoms. Dysmenorrhea is a gynecological complaint due to an imbalance of the progesterone in the blood, thus causing menstrual pain in women. The production of prostaglandins in women with dysmenorrhea was 10 times higher than in women without dysmenorrhea (Nurwana et al, 2017).

Dysmenorrhea is classified into two, namely primary and secondary dysmenorrhea. Primary dysmenorrhea is caused by natural chemicals produced by cells of the lining of the uterus called prostaglandins (Nurwana et al., 2017). Secondary dysmenorrhea occurs due to gynecological abnormalities or other factors (Irianto, 2015).

Factors that can affect dysmenorrhea are psychological factor (stress), low pain threshold, menarche at an earlier age, period length, abnormal BMI, lifestyle, and family history. Factors that often occur during dysmenorrhea are psychological factor (stress). Stress can disrupt the endocrine system. It also causes menstrual cramps. In addition, psychological factors are essential to dysmenorrhea because pain can occur due to indivi- dual psychological or emotional states, thus causing disorder or insomnia (Ilmi et al., 2017).

Non-pharmacological management of dysmenorrhea is acupuncture therapy. Acupuncture therapy is very helpful because it can reduce the pain of dysmenorrhea by stimulating acupuncture points. It can engage the central nervous system to produce the effects of releasing $\beta$-endorphins and enkephalin, thus releasing pain (Oktobriariani, 2016). Acupuncture therapy can reduce the severity of pain and other symptoms during dysmenorrhea, thus improving the quality of life in carrying out daily activities (Caroline et al., 2011). Acupuncture therapy is considered by the public as a complementary treatment that is safely used in dysmenorrhea treatment (Smith et al., 2011).

Acupuncture therapy greatly affects prevention and treatment which is considered to be effective in reducing pain in dysmenorrhea due to the high number of the incidence of dysmenorrhea. Therefore, the study of "Effect of acupuncture therapy on pain reduction in dysmenorrhea patients: A meta-analysis" was conducted to see the effectiveness of acupuncture therapy in dysmenorrhea patients.

\section{SUBJECTS AND METHOD}

\section{Study Design}

This study was a systematic study and a meta-analysis. The articles were obtained from several databases including PubMed, Google scholar, and Hindawi. The keywords were "acupuncture pain" OR "acupuncture primary dysmenorrhea" AND "acupuncture for dysmenorrhea" AND "randomized controlled trial".

\section{Inclusion Criteria}

The included articles were full-text articles with a randomized controlled trial study design. The study subjects were dysmenorrhea patients aged $14-40$ years. The 
Novitasari et al./ Acupuncture Therapy and Pain Reduction in Dysmenorrhea Patients

selected articles discussed acupuncture therapy with pain reduction as the outcome. The intervention was in the form of acupuncture therapy with pain reduction in dysmenorrhea patients as the outcome.

\section{Exclusion Criteria}

The excluded articles were articles with nonRCT study design, non-full-text articles, study subjects (women) with other gynecological diseases.

\section{Operational Definition of Variables}

The article search was carried out by considering the eligibility criteria defined using the PICO model. The population of this study was dysmenorrhea patients aged 14-40 years. The intervention was in the form of acupuncture therapy. The comparison was no acupuncture therapy. The outcome was in the form of pain reduction.

Dysmenorrhea pain was pain during menstruation that occurred due to contractions in the uterus or uterine muscles. It was a cramp in the lower abdomen. Instrument: Visual Analogue Scale (VAS) with continuous measuring scale.

Acupuncture therapy was a complementary treatment by inserting needles at acupoints. It aimed to stimulate the body to heal by activating the nervous system, immune system, and blood circulation which could reduce the pain length. Instrument: Medical records with categorical measuring scale.

\section{Data Analysis}

The data were processed using the Review Manager (RevMan 5.3) by calculating the standardized mean differences to determine the combined study model. The result was in the form of a meta-analysis.

\section{RESULTS}

The process of searching for articles by conducting database searches with PRISMA flow diagram is in Figure 1.

\section{Removed duplicate} data $(n=79)$

Excluded articles $(\mathrm{n}=784)$

1. Irrelevant titles $=643$

2. Non-full-text articles $=13$

3. Non-English articles $=10$

4. Non-RCT study design $=118$

Excluded full-text articles $(n=39)$

1. Non-primary dysmenorrhea articles $=23$

2. Unmatched outcome $=16$
Articles included in the qualitative synthesis $(\mathrm{n}=10)$

Articles included in the qualitative synthesis of a metaanalysis $(n=7)$ 
Novitasari et al./ Acupuncture Therapy and Pain Reduction in Dysmenorrhea Patients

\section{Table 1 Assessment of Quality Study}

\begin{tabular}{|c|c|c|c|c|c|c|c|c|c|c|c|c|}
\hline \multirow[b]{2}{*}{ Checklist questions } & \multicolumn{3}{|c|}{ Cha et al. (2016) } & \multicolumn{3}{|c|}{ Chen et al. (2010) } & \multicolumn{3}{|c|}{ Gilarranz et al.(2018) } & \multicolumn{3}{|c|}{ Pei et al.(2016) } \\
\hline & Yes & $\begin{array}{l}\text { No expla- } \\
\text { nation }\end{array}$ & No & Yes & $\begin{array}{l}\text { No expla- } \\
\text { nation }\end{array}$ & No & Yes & $\begin{array}{l}\text { No expla- } \\
\text { nation }\end{array}$ & No & Yes & $\begin{array}{l}\text { No expla- } \\
\text { nation }\end{array}$ & No \\
\hline Did this study discuss a clear study focus? & $\sqrt{ }$ & & & $\sqrt{ }$ & & & $\sqrt{ }$ & & & $\sqrt{ }$ & & \\
\hline $\begin{array}{l}\text { Was the Randomized Controlled Trial research } \\
\text { method suitable for answering study questions? }\end{array}$ & $\sqrt{ }$ & & & $\sqrt{ }$ & & & $\sqrt{ }$ & & & $\sqrt{ }$ & & \\
\hline $\begin{array}{l}\text { Were there enough subjects in the study to } \\
\text { establish that the findings were not made by } \\
\text { chance? }\end{array}$ & $\sqrt{ }$ & & & $\sqrt{ }$ & & & $\sqrt{ }$ & & & $\sqrt{ }$ & & \\
\hline $\begin{array}{l}\text { Were the subjects randomly allocated to the } \\
\text { experimental and control groups? If not, could } \\
\text { this be biased? }\end{array}$ & $\sqrt{ }$ & & & $\sqrt{ }$ & & & $\sqrt{ }$ & & & $\sqrt{ }$ & & \\
\hline Were the inclusion/exclusion criteria used? & $\sqrt{ }$ & & & $\sqrt{ }$ & & & $\sqrt{ }$ & & & $\sqrt{ }$ & & \\
\hline $\begin{array}{l}\text { Were the two groups comparable at the } \\
\text { beginning of this study? }\end{array}$ & $\sqrt{ }$ & & & $\sqrt{ }$ & & & $\sqrt{ }$ & & & $\sqrt{ }$ & & \\
\hline $\begin{array}{l}\text { Were objective and unbiased outcome criteria } \\
\text { used? }\end{array}$ & $\sqrt{ }$ & & & $\sqrt{ }$ & & & $\sqrt{ }$ & & & $\sqrt{ }$ & & \\
\hline $\begin{array}{l}\text { Were objective and validated measurement } \\
\text { methods used to measure the results? If not, } \\
\text { were the results scored by someone who did not } \\
\text { know the group assignment (i.e. was the } \\
\text { assessment blinded? }\end{array}$ & $\sqrt{ }$ & & & $\sqrt{ }$ & & & $\sqrt{ }$ & & & $\sqrt{ }$ & & \\
\hline Was the effect size practically relevant? & $\sqrt{ }$ & & & $\sqrt{ }$ & & & $\sqrt{ }$ & & & $\sqrt{ }$ & & \\
\hline $\begin{array}{l}\text { How precise was the estimated effect? Was there } \\
\text { a confidence interval? }\end{array}$ & $\sqrt{ }$ & & & $\sqrt{ }$ & & & $\sqrt{ }$ & & & $\sqrt{ }$ & & \\
\hline $\begin{array}{l}\text { Could there be confounding factors that have not } \\
\text { been considered? }\end{array}$ & $\sqrt{ }$ & & & $\sqrt{ }$ & & & $\sqrt{ }$ & & & $\sqrt{ }$ & & \\
\hline Were the results applicable to your study? & $\sqrt{ }$ & & & $\sqrt{ }$ & & & $\sqrt{ }$ & & & $\sqrt{ }$ & & \\
\hline
\end{tabular}


Novitasari et al./ Acupuncture Therapy and Pain Reduction in Dysmenorrhea Patients

\begin{tabular}{|c|c|c|c|c|c|c|c|}
\hline \multirow[b]{2}{*}{ Checklist questions } & \multicolumn{3}{|c|}{ Shetty et al. (2018) } & \multicolumn{2}{|r|}{ Shi et al. (2010) } & \multicolumn{2}{|c|}{ Wong et al. (2010) } \\
\hline & Yes & $\begin{array}{c}\text { No } \\
\text { explanation }\end{array}$ & No & Yes & $\begin{array}{c}\text { No } \\
\text { explanation }\end{array}$ & Yes & $\begin{array}{cc}\text { No } & \text { No } \\
\text { explanation } & \\
\end{array}$ \\
\hline Did this study discuss about a clear study focus? & $\sqrt{ }$ & & & $\sqrt{ }$ & & $\sqrt{ }$ & \\
\hline $\begin{array}{l}\text { Was the Randomized Controlled Trial research method suitable } \\
\text { for answering study questions? }\end{array}$ & $\sqrt{ }$ & & & $\sqrt{ }$ & & $\sqrt{ }$ & \\
\hline $\begin{array}{l}\text { Were there enough subjects in the study to establish that the } \\
\text { findings were not made by chance? }\end{array}$ & $\sqrt{ }$ & & & $\sqrt{ }$ & & $\sqrt{ }$ & \\
\hline $\begin{array}{l}\text { Were the subjects randomly allocated to the experimental and } \\
\text { control groups? If not, could this be biased? }\end{array}$ & $\sqrt{ }$ & & & $\sqrt{ }$ & & $\sqrt{ }$ & \\
\hline Were the inclusion/exclusion criteria used? & $\sqrt{ }$ & & & $\sqrt{ }$ & & $\sqrt{ }$ & \\
\hline Were the two groups comparable at the beginning of this study? & $\sqrt{ }$ & & & $\sqrt{ }$ & & $\sqrt{ }$ & \\
\hline Were objective and unbiased outcome criteria used? & $\sqrt{ }$ & & & $\sqrt{ }$ & & $\sqrt{ }$ & \\
\hline $\begin{array}{l}\text { Were objective and validated measurement methods used to } \\
\text { measure the results? If not, were the results scored by someone } \\
\text { who did not know the group assignment (i.e. was the } \\
\text { assessment blinded? }\end{array}$ & $\sqrt{ }$ & & & $\sqrt{ }$ & & $\sqrt{ }$ & \\
\hline Was the effect size practically relevant? & $\sqrt{ }$ & & & $\sqrt{ }$ & & $\sqrt{ }$ & \\
\hline $\begin{array}{l}\text { How precise was the estimated effect? Was there a confidence } \\
\text { interval? }\end{array}$ & $\sqrt{ }$ & & & $\sqrt{ }$ & & $\sqrt{ }$ & \\
\hline $\begin{array}{l}\text { Could there be confounding factors that have not been } \\
\text { considered? }\end{array}$ & $\sqrt{ }$ & & & $\sqrt{ }$ & & $\sqrt{ }$ & \\
\hline Were the results applicable to your study? & $\sqrt{ }$ & & & $\sqrt{ }$ & & $\sqrt{ }$ & \\
\hline
\end{tabular}

$\checkmark$ yes 
1. Acupuncture therapy on pain reduction

Table 2. 7 The article proved that acupuncture therapy was related to pain reduction in dysmenorrhea patients

\begin{tabular}{|c|c|c|c|c|c|c|c|}
\hline $\begin{array}{c}\text { Author } \\
\text { (year) }\end{array}$ & Country & $\begin{array}{c}\text { Study } \\
\text { Design }\end{array}$ & Sample & $\begin{array}{c}\mathbf{P} \\
\text { (Populatio } \\
\mathbf{n})\end{array}$ & $\begin{array}{c}\text { I } \\
\text { (Intervention) }\end{array}$ & $\begin{array}{c}\text { C } \\
\text { (Comparison) }\end{array}$ & $\begin{array}{c}\text { O } \\
\text { (Outcome) }\end{array}$ \\
\hline $\begin{array}{l}\text { Cha et al. } \\
\text { (2016) }\end{array}$ & $\begin{array}{l}\text { South } \\
\text { Korea }\end{array}$ & $\begin{array}{l}\text { Randomi } \\
\text { zed Con- } \\
\text { trolled } \\
\text { Trial. }\end{array}$ & $\begin{array}{l}\text { Acupuncture } \\
: 45 \\
\text { No } \\
\text { acupuncture : } \\
46\end{array}$ & $\begin{array}{l}\text { Dysmenorrhe } \\
\text { a patients } \\
\text { aged 14-25 } \\
\text { years }\end{array}$ & $\begin{array}{l}\text { This study compared the effect of } \\
\text { acupuncture therapy in dys- } \\
\text { menorrhea patients as an } \\
\text { abdominal pain reduction*, back } \\
\text { pain during dysmenorrhea } \\
\text { measured before and after in both } \\
\text { groups. }\end{array}$ & $\begin{array}{l}\text { There was no effect of } \\
\text { non-acupuncture therapy } \\
\text { in primary dysmenor- } \\
\text { rhea patients as pain } \\
\text { reduction in the two } \\
\text { groups. }\end{array}$ & $\begin{array}{l}\text { Pain reduction } \\
\text { in dysmenor- } \\
\text { rhea patients }\end{array}$ \\
\hline $\begin{array}{l}\text { Chen et } \\
\text { al. } \\
(2010)\end{array}$ & Taiwan & $\begin{array}{l}\text { Randomi } \\
\text { zed Con- } \\
\text { trolled } \\
\text { Trial }\end{array}$ & $\begin{array}{l}\text { Acupuncture } \\
: 36 \\
\text { No } \\
\text { acupuncture : } \\
35\end{array}$ & $\begin{array}{l}\text { Dysmenorrhe } \\
\text { a patients } \\
\text { aged 14-19 } \\
\text { years }\end{array}$ & $\begin{array}{l}\text { This study compared the effect of } \\
\text { acupuncture therapy in dysme- } \\
\text { norrhea patients as a pain* and } \\
\text { anxiety reduction during dysme- } \\
\text { norrhea as measured before and } \\
\text { after in both groups. }\end{array}$ & $\begin{array}{l}\text { There was no effect of } \\
\text { non-acupuncture therapy } \\
\text { from dysmenorrhea } \\
\text { patients to both groups. }\end{array}$ & $\begin{array}{l}\text { Pain reduction } \\
\text { in dysmenor- } \\
\text { rhea patients }\end{array}$ \\
\hline $\begin{array}{l}\text { Gilarranz } \\
\text { et al. } \\
\text { (2018) }\end{array}$ & Spain & $\begin{array}{l}\text { Randomi } \\
\text { zed Con- } \\
\text { trolled } \\
\text { Trial. }\end{array}$ & $\begin{array}{l}\text { Acupuncture } \\
: 19 \\
\text { No acupunc- } \\
\text { ture : } 19\end{array}$ & $\begin{array}{l}\text { Dysmenorrhe } \\
\text { a patients } \\
\text { aged 18-25 } \\
\text { years }\end{array}$ & $\begin{array}{l}\text { This study compared the effecti- } \\
\text { veness of acupuncture therapy on } \\
\text { pain reduction in dysmenorrhea } \\
\text { patients }\end{array}$ & $\begin{array}{l}\text { There was no compa- } \\
\text { rison of the effectiveness } \\
\text { of the control group that } \\
\text { was not given acupunc- } \\
\text { ture therapy in reducing } \\
\text { dysmenorrhea pain. }\end{array}$ & $\begin{array}{l}\text { Pain reduction } \\
\text { in dysmenor- } \\
\text { rhea patients }\end{array}$ \\
\hline $\begin{array}{l}\text { Pei et al. } \\
(2016)\end{array}$ & China & $\begin{array}{l}\text { Randomi } \\
\text { zed Con- } \\
\text { trolled } \\
\text { Trial. }\end{array}$ & $\begin{array}{l}\text { Acupuncture } \\
: 164 \\
\text { No acupunc- } \\
\text { ture: } 165\end{array}$ & $\begin{array}{l}\text { Dysmenorrhe } \\
\text { a patients } \\
\text { aged 13-18 } \\
\text { years }\end{array}$ & $\begin{array}{l}\text { This study aimed to assess the } \\
\text { effect of acupuncture therapy in } \\
\text { reducing pain intensity in dys- } \\
\text { menorrhea patients, measured } \\
\text { before and after therapy. }\end{array}$ & $\begin{array}{l}\text { There was no effect of } \\
\text { non-acupuncture therapy } \\
\text { on reducing pain } \\
\text { intensity in dysmenor- } \\
\text { rhea patients }\end{array}$ & $\begin{array}{l}\text { Pain reduction } \\
\text { in dysmenor- } \\
\text { rhea patients }\end{array}$ \\
\hline $\begin{array}{l}\text { Shetty et } \\
\text { al. } \\
\text { (2018) }\end{array}$ & India & $\begin{array}{l}\text { Randomi } \\
\text { zed Con- } \\
\text { trolled } \\
\text { Trial. }\end{array}$ & $\begin{array}{l}\text { Acupuncture } \\
: 30 \\
\text { No acu- } \\
\text { puncture : } 30\end{array}$ & $\begin{array}{l}\text { Dysmenorrhe } \\
\text { a patients } \\
\text { aged } 17-23 \\
\text { years }\end{array}$ & $\begin{array}{l}\text { This study aimed to evaluate the } \\
\text { efficiency of pain in dysmenor- } \\
\text { rhea patients by providing } \\
\text { acupuncture therapy in the pain }\end{array}$ & $\begin{array}{l}\text { There was no evaluation } \\
\text { of the efficiency of giving } \\
\text { non-acupuncture on the } \\
\text { pain * dizziness, }\end{array}$ & $\begin{array}{l}\text { Pain reduction } \\
\text { in dysmenor- } \\
\text { rhea patients }\end{array}$ \\
\hline
\end{tabular}




\begin{tabular}{|c|c|c|c|c|c|c|c|}
\hline $\begin{array}{c}\text { Author } \\
\text { (year) }\end{array}$ & Country & $\begin{array}{c}\text { Study } \\
\text { Design }\end{array}$ & Sample & $\begin{array}{c}\mathbf{P} \\
\text { (Populatio } \\
\mathbf{n})\end{array}$ & $\begin{array}{c}\text { I } \\
\text { (Intervention) }\end{array}$ & $\begin{array}{c}\mathrm{C} \\
\text { (Comparison) }\end{array}$ & $\begin{array}{c}\text { O } \\
\text { (Outcome) }\end{array}$ \\
\hline $\begin{array}{l}\text { Shi et al. } \\
\text { (2010) }\end{array}$ & China & $\begin{array}{l}\text { Randomi } \\
\text { zed Con- } \\
\text { trolled } \\
\text { Trial. }\end{array}$ & $\begin{array}{l}\text { Acupuncture: } \\
10 \\
\text { No acu- } \\
\text { puncture: } 10\end{array}$ & $\begin{array}{l}\text { Dysmenorrhe } \\
\text { a patients } \\
\text { aged 15-30 } \\
\text { years }\end{array}$ & $\begin{array}{l}\text { *, dizziness, diarrhea, nausea and } \\
\text { vomiting groups measured before } \\
\text { and after therapy. } \\
\text { This study aimed to see the effect } \\
\text { of analgesic mechanism in } \\
\text { acupuncture therapy on dysme- } \\
\text { norrhea pain reduction measured } \\
\text { before and after. }\end{array}$ & $\begin{array}{l}\text { diarrhea, nausea and } \\
\text { vomiting groups in } \\
\text { dysmenorrhea patients } \\
\text { There was no effect of } \\
\text { the analgesic mechanism } \\
\text { on no acupuncture } \\
\text { therapy on the reduction }\end{array}$ & $\begin{array}{l}\text { Pain reduction } \\
\text { in dysmenor- } \\
\text { rhea patients }\end{array}$ \\
\hline $\begin{array}{l}\text { Wong et } \\
\text { al. (2010) }\end{array}$ & $\begin{array}{l}\text { Hong } \\
\text { Kong }\end{array}$ & $\begin{array}{l}\text { Randomi } \\
\text { zed Con- } \\
\text { trolled } \\
\text { Trial. }\end{array}$ & $\begin{array}{l}\text { Acupuncture : } \\
19 \\
\text { No acu- } \\
\text { puncture: } 21\end{array}$ & $\begin{array}{l}\text { Dysmenorrhe } \\
\text { a patients } \\
\text { aged 14-25 } \\
\text { years }\end{array}$ & $\begin{array}{l}\text { This study aimed to evaluate the } \\
\text { effect of acupuncture therapy on } \\
\text { pain reduction in dysmenorrhea } \\
\text { measured before and after pain. }\end{array}$ & $\begin{array}{l}\text { There was no evaluation } \\
\text { of the effect of no acu- } \\
\text { puncture therapy in dys- } \\
\text { menorrhea pain patients }\end{array}$ & $\begin{array}{l}\text { Pain reduction } \\
\text { in dysmenor- } \\
\text { rhea patients }\end{array}$ \\
\hline
\end{tabular}

\section{Forest plot}

\begin{tabular}{|c|c|c|c|c|c|c|c|c|c|c|}
\hline \multirow[b]{2}{*}{ Study or Subgroup } & \multicolumn{3}{|c|}{ Acupuncture } & \multicolumn{3}{|c|}{ No Acupuncture } & \multicolumn{2}{|r|}{ Std. Mean Difference } & \multirow{2}{*}{\multicolumn{2}{|c|}{$\begin{array}{l}\text { Std. Mean Difference } \\
\text { IV, Random, } 95 \% \mathrm{Cl}\end{array}$}} \\
\hline & Mean & SD 1 & Total $\mathrm{N}$ & Mean & SD & Total & Weight & IV, Random, $95 \% \mathrm{Cl}$ & & \\
\hline Cha 2016 & 3.01 & 2.68 & 45 & 4.62 & 2.54 & 46 & $15.2 \%$ & $-0.61[-1.03,-0.19]$ & - & \\
\hline Chen 2010 & 1.93 & 1.59 & 36 & 4.45 & 1.94 & 35 & $14.8 \%$ & $-1.41[-1.93,-0.88]$ & & \\
\hline Gilarranz 2018 & 29.4 & 22.5 & 19 & 46.2 & 24.1 & 19 & $14.3 \%$ & $-0.71[-1.36,-0.05]$ & & \\
\hline Pei 2016 & 30 & 17 & 164 & 28 & 18 & 165 & $15.8 \%$ & $0.11[-0.10,0.33]$ & & $\sigma$ \\
\hline Shetty 2018 & 2.53 & 1.68 & 30 & 7.17 & 1.42 & 30 & $13.8 \%$ & $-2.94[-3.69,-2.20]$ & $\longleftarrow$ & \\
\hline Shi 2010 & 25.7 & 12.96 & 10 & 48.2 & 7.25 & 10 & $11.8 \%$ & $-2.05[-3.18,-0.92]$ & & \\
\hline Wong 2010 & 2.79 & 1.58 & 19 & 4.3 & 1.74 & 21 & $14.3 \%$ & $-0.89[-1.54,-0.23]$ & & \\
\hline Total $(95 \% \mathrm{Cl})$ & & & 323 & & & 326 & $100.0 \%$ & $-1.16[-1.92,-0.41]$ & & \\
\hline \multicolumn{9}{|c|}{$\begin{array}{l}\text { Heterogeneity: } \text { Tau }^{2}=0.93 ; \mathrm{Ch}^{2}=92.83, \mathrm{df}=6(\mathrm{P}<0.00001) ; 1^{2}=94 \% \\
\text { Test for overall effect: } Z=3.01(P=0.003)\end{array}$} & $\begin{array}{ccc} & -1 & 0 \\
& -1 & 0 \\
& \text { Acupuncture }\end{array}$ & $\begin{array}{cc}0 & 1 \\
\text { No } & \text { Acupuncth }\end{array}$ \\
\hline
\end{tabular}

Figure 2. Forest plot of the effect of acupuncture therapy on pain reduction 


\section{Funnel plot}

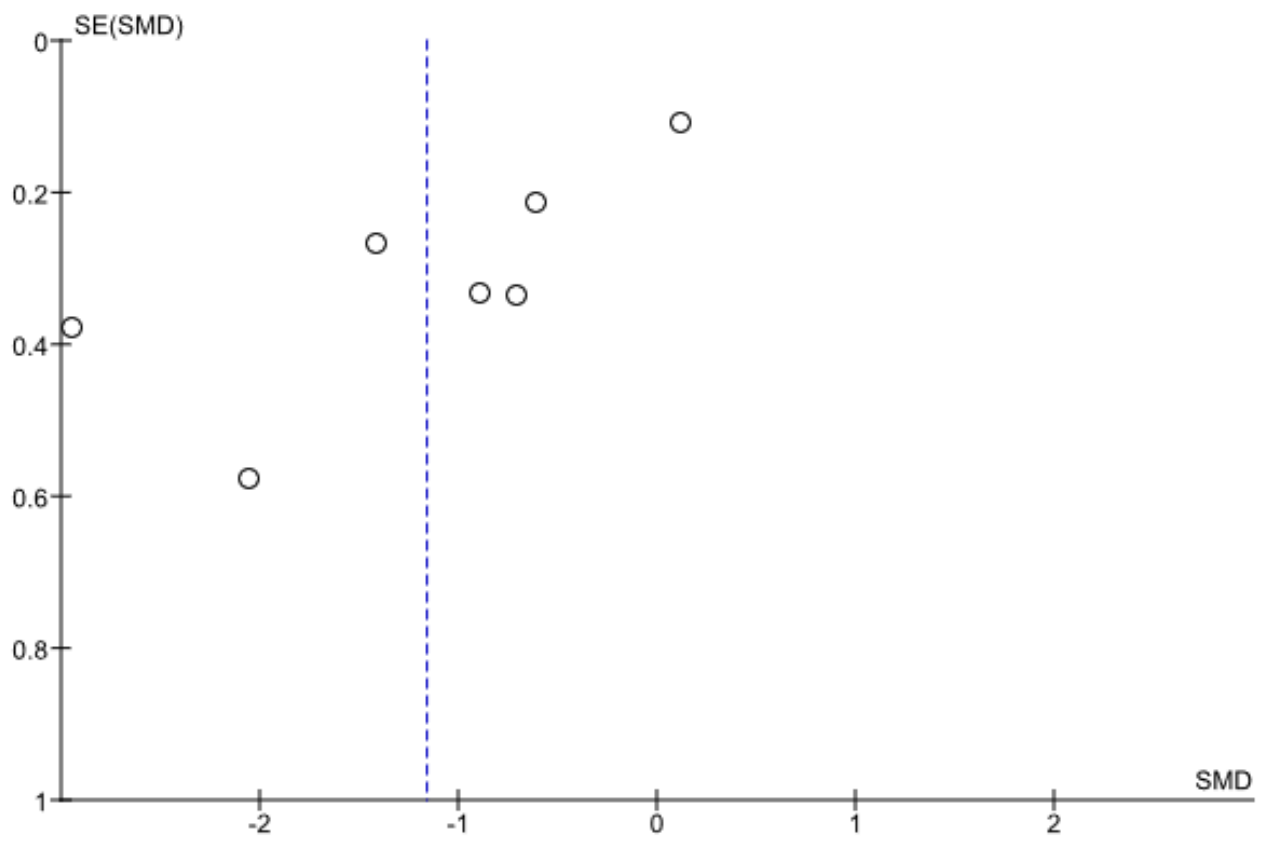

Figure 3. Funnel plot of the effect of acupuncture therapy on pain reduction

Based on the result of the forest plot (Figure 2), acupuncture therapy was -1.16 times better in reducing pain in dysmenorrhea patients than no acupuncture therapy. It was statistically significant $(\mathrm{p}=0.003)$. The heterogeneity of the data was $\mathrm{I}^{2}=94 \%$, Therefore, the distribution of the data was heterogeneous (random effect model).

The funnel plot (Figure 3) showed a publication bias characterized by the asymmetry of the right and left plots with 4 plots on the right and 3 plots on the left. The plot on the left had a standard error of between 0.2 and o.6. The plot on the right had a standard error of between 0.0 and 0.4. Bias occurred due to the imbalance between the distances among studies on both the right and left of the funnel plot.

\section{DISCUSSION}

The theme of the systematic study and metaanalysis was the effect of acupuncture therapy on pain reduction in dysmenorrhea patients. This study was considered important due to its rarity. The number of the relevant and accessible study published was not quite large and also had data access problems (duplicate data) (Murti, 2018).

The confounding factor affecting the relationship or effect of exposure to the occurrence of the disease estimated by the study was not the same as the relationship or effect that occurred in the target population: it is the same as the invalid study results (Murti, 2018). The estimation of the combined effects of acupuncture therapy on pain reduction in dysmenorrhea patients was processed using RevMan 5.3 with a continuous method. This method aimed to analyze the effect size or standardized mean difference in bivariate data from two groups that had been controlled for confounding factors by randomization.

The results of the systematic study and meta-analysis were presented in the form of a forest plot and a funnel plot. Forest plot showed an overview of information from each of the studies examined in the metaanalysis and the estimation of the overall results (Murti, 2018). The forest plot showed 
Novitasari et al./ Acupuncture Therapy and Pain Reduction in Dysmenorrhea Patients

visually the amount of variation (heterogeneity) among study results (Akobeng in Murti, 2018).

A funnel plot was a diagram in a metaanalysis that was commonly used to demonstrate possible publication bias. The funnel plot showed the relationship between the effect size and the sample size or the standard error of the effect size of the various studies studied (Murti, 2018).

The systematic review and meta-analysis in this study aimed to increase the generalizability of the findings and obtain convincing conclusions from the results of various similar studies. The result showed that acupuncture therapy was $\mathbf{- 1 . 1 6}$ better in reducing pain in dysmenorrhea patients than non-acupuncture therapy.

Based on a study conducted by Shi et al (2010), acupuncture therapy was more effecttive in reducing dysmenorrhea pain than no acupuncture. This study recommended acupuncture therapy because it was safe, efficient, and had a significant effect on reducing dysmenorrhea pain.

This study is in line with a study conducted by Liu et al (2011). This study proved that the acupuncture therapy group had decreased dysmenorrhea pain (SMD -15.56; 95\% $\mathrm{CI}=-\mathbf{2 2 . 1 6}$ to $-8.95 ; \mathrm{p}<0.001)$. However, there was a non-significant effect in the control group without acupuncture therapy.

This study is in line with a study conducted by Shetty et al (2018) that a study with acupuncture therapy could have a significant effect on reducing dysmenorrhea pain compared to non-acupuncture therapy.

\section{AUTHOR CONTRIBUTION}

Elisa was the main researcher who selected the topic, explored, and collected the data. RB Soemanto and Hanung Prasetya analyzed the data and reviewed the documents of the study.

\section{CONFLICT OF INTEREST}

This study did not have a conflict of interest.

\section{FUNDING AND SPONSORSHIP}

This study used personal funds from the main researcher.

\section{ACKNOWLEDGEMENT}

We would like to thank the database providers, PubMed, Google Scholar, and Hindawi

\section{REFERENCE}

Caroline A, Smith CAC, Oswald P, Justin B, Hannah D (2011). Acupuncture to treat primary dismenore in women : a randomized controlled trial, Evid. Based Complementary Altern. Med.

Cha N, Sok S (2016). Effects of auricular acupressure therapy on primary dysmenorrhea for female high school students in South Korea. J Nurs Scholarsh, 1-9

Chen HM (2010). Effects of acupressure on menstrual distress in adolescent girls: a comparison between heg-sanyinjiao matched point and hegu, zusanli single point. J Clin Nurs, 19, 998-1007. DOI: 10.1111/j.1365-2702.2009.02872.x

Gilarranz, Cesar et al (2018). Effectiveness of dry needling of rectus abdominis trigger points for the treatment of primary dysmenorrhea: a randomized parallel-group trial. Med Acupunct, o: 1-9.

Ilmi M, Fahrurazi, Mahrita (2017). Dismenore sebagai faktor stres pada remaja putri kelas X dan XI di SMA Kristen Kanaan Banjarmasin. Available at : http://openjurnal.unmuhpnk.ac.id/ind ex.php/JKMK/article/view/864

Irianto K (2015). Kesehatan reproduksi (reproductive health) teori dan praktikum. bandung : Alfabeta. Hal : 296 297.

Joshi T, Kural M, Agarwal DP, Noor NN dan 
Novitasari et al./ Acupuncture Therapy and Pain Reduction in Dysmenorrhea Patients

Patil A (2105). Primary dysmenorrhea and its effect on quality of life in young girls. Sci eng ethics, 4(3):381-385.

Murti B (2018). Prinsip dan Metode Riset Epidemiologi. Edisi V. Program Studi Ilmu Kesehatan Masyarakat, Program Pascasarjana, Universitas Sebelas Maret. Surakarta. Bintang Fajar Offsite Colomadu, Karanganyar, Jawa Tengah. Nurwana, Sabilu Y, Fachlevy A (2017). Analisis faktor yang berhubungan dengan kejadian disminorea pada remaja putri di SMA Negeri 8 Kendari Tahun 2016. Jurnal Ilmiah Mahasiswa Kesehatan Masyarakat Unsyiah, 2 (6) : 1 - 14 .

Oktobriariani R, Ratnasari R (2016). Pengaruh akupuntur terhadap penurunan nyeri haid (dismenore) pada mahasiswi D III Kebidanan Universitas Muhammadiyah Ponorogo. IOSR Journal of Economics and Finance, 3 (1) : 1 217. Available at : https://doi.org/10.3929/ethz-b-000238666.

Rahayu A, Pertiwi S, Patimah S (2017). Pengaruh endorphine massage terhadap rasa sakit dismenore pada mahasiswi Jurusan Kebidanan Poltekkes Kemenkes Tasikmalaya Tahun 2017. Jurnal Bidan "Midwife Journal", 3 (2). Shi GX, Liu CL, Zhu J, Guan LP, Wang DJ,
Wu MM (2010). Effects of acupuncture at sanyinjiao (SP6) on prostaglandin levels in primary dysmenorrhea patients. Clinical pain. 27(3): 258-61. https://doi.org/10.1097/ajp.obo13e3181fb27ae.

Shetty GB, Shetty B, Mooventhan A (2018). Efficacy of acupuncture in the management of primary dysmenorrhea: a randomized controlled trial. J acupunct meridian stud, 11(4): 153-158. https://doi.org/10.1016/j.jams.2018.04.001.

Yu S, Yang J, Yang M, Gao Y, Chen J, Ren Y, Zhang L, Chen L, Liang F, Hu Y (2014). Application of acupoints and meridians for the treatment of primary dysmenorrhea: A data mining-based literature study. Evid. Based complementary altern. Med. https://doi.org/10.1155/2015/752194.

Wong LP, Khoo EM (2010). Dysmenorrhea in a multiethnic population of adolescent Asian girls. BMC health services research. 108(2):139-42. https://doi.org/10.1016/j.ijgo.2009.09.018.

Wong (2010). Effects of SP 6 acupressure on pain and menstrual distress in young women with dysmenorrhea. Complement Ther Clin Pract. 16: 64-69. https://doi.org/10.1016/j.ctcp.2009.10.002. 